\title{
ACTIVITY OF DEHYDROGENASES AND ENZYMES OF NITROGEN METABOLISM \\ IN CARDIAC TISSUE AND SKELETAL MUSCLE OF STEERS FED MONENSIN
}

\author{
G. I. KALAČNJUK ${ }^{1}$, M. MAROUNEK ${ }^{2}$, L. G. KALAČNJUK ${ }^{3}$, M. G. GERASYMIV, O. G. SAVKA
}

\author{
${ }^{1}$ Institute of Animal Physiology and Biochemistry, 290034 Lviv, Ukraine \\ ${ }^{2}$ Institute of Animal Physiology and Genetics, 10400 Prague 10 - Uhříněves, Czech Republic \\ ${ }^{3}$ Institute of Molecular Biology and Genetics, $252627 \mathrm{Kiev}$, Ukraine
}

Received October 25, 1994

Accepted May 30, 1995

\begin{abstract}
Ka la żn juk G. I., M. Marounek, L. G. Ka la žn juk, M. G. Geras ymiv, O. G. $\mathrm{S}$ a v k a : Activity of Dehydrogenases and Enzymes of Nitrogen Metabolism in Cardiac Tissue and Skeletal Muscle of Steers fed Monensin. Acta vet. Brno 1995, 64:157-161.

Activites of lactate dehydrogenase (E.C. 1.1.1.27), malate dehydrogenase (E.C.1.1.1.40), 2-oxoglutarate dehydrogenase, (E.C.1.2.4.2) glutamate dehydrogenase (E.C.1.4.1.3), glutamin synthetase (E.C.6.3.1.2), arginase (E.C.3.5.3.1), ornithine carbamoyltransferase (E.C.2.1.3.3), aspartate aminotransferase (E.C.2.6.1.1) and alanine aminotransferase (E.C.2.6.1.2) were measured in cardic and skeletal muscles of steers fed ration with or without monensin. Steers, 9 months old at the beginning, were fed concentrate, molasses, grass, lucerne and maize chaff. Five steers received monensin in amount of $0.5 \mathrm{mg}$ per $1 \mathrm{~kg}$ of live body mass per day. Control ration, without monensin was fed to the other five steers. After 10 months steers were slaughtered and activity of enzymes assayed in the mitochondrial and cytoplasmic fraction of cells. Monensin increased activity of 2-oxoglutarate dehydrogenase and decreased activity of glutamate dehydrogenase in both fractions of the skeletal muscle tissue. Enzymatic activities found in heart mitochondria were higher in monensin-fed steers than in control steers. Steers given monensin gained $8.23 \%$ more than control steers (263vs $243 \mathrm{~kg})$.
\end{abstract}

Monensin, enzyme, heart, muscle

Feed antibiotics, including monensin, have the ability to improve performance and feed efficiency in ruminants. It is known that monensin is absorbed from the alimentary tract ( $\mathrm{D}$ a vi s o n 1983; D o n o h o 1984) and several authors demonstrated its influence on intermediary metabolism of ruminants (A rm strong and S pears 1988; B en z et al. 1989; Marou ne k et al. 1989). Little is known about the effect of monensin on activity of tissue enzymes in ruminants. K a l a č $\mathrm{nj} \mathrm{u} \mathrm{k}$ et al. (1993) measured activity of various enzymes in rumen mucosa and liver of steers fed monensin at recommended level. Authors found no consistent effect of monensin on enzymes of both tissues. In this paper we report data on activity of nine enzymes in cardiac and skeletal muscles of steers fed ration with or without monensin for ten months. Cardiac and skeletal muscles are primary target tissues at high intake of monensin ( $\mathrm{T} \mathrm{o} \mathrm{d} \mathrm{d} \mathrm{et}$ al. 1984; V a n V le et et al. 1985) and, presumably, also during long-term supplementation of rations under normal feeding conditions.

\section{Materials and Methods}

Ten crossbred steers, 9 months old at the beginning of experiment, were divided into two groups, according to feed additive treatment. Steers were individually housed and kept on a diet consisting of concentrate $(1 \mathrm{~kg}$ per 100 $\mathrm{kg}$ of the live weight), molasses $(0.5-1.0 \mathrm{~kg})$ and grass, lucerne and maize chaff ad libitum. In winter, the roughage portion of the diet consisted of maize silage and beet ad libitum. Concentrate contained ground barley (63\%), dried poultry litter from broilers which did not receive a ionophore in their diet (20\%), grass meal (15\%) and zeolite (2\%). 
Five steers received monensin (Elanco, USA) in amount of $0.5 \mathrm{mg}$ per $1 \mathrm{~kg}$ of live weight daily. Initial weight of steers was $209 \mathrm{~kg}$ and $206 \mathrm{~kg}$ in the control and treated group, respectively. After 10 months steers were slaughtered, samples of tissues taken (heart, musculus longissimus dorsi) and stored in liquid nitrogen until analyzed. Samples were pulverized and homogenized in the Potter-Elvehjem homogenizer. Mitochondrial and cytosolic fraction of cells were obtained by differential centrifugation according to $\mathrm{H}$ o $\mathrm{g} \mathrm{e} \mathrm{b} \mathrm{o} \mathrm{o} \mathrm{m}$ (1955). Activities of nine enzymes were assayed at $37^{\circ} \mathrm{C}$ in extracts, which were prepared by method of $\mathrm{M} \mathrm{o} \mathrm{t}$ o $\mathrm{n}$ (1955). Lactate dehydrogenase (LDH), malate dehydrogenase (MDH), 2-oxoglutarate dehydrogenase (OGDH), glutamate dehydrogenase (GDH), glutamin synthetase (GS), arginase (A), and ornithine carbamoyltransferase (OCT) were assayed using established methods, which were compiled by C o 11 o w i c k and K a p l a n (1955 a,b). Aspartate aminotransferase (AST) and alanine aminotransferase (ALT) activities were determined using Bio-la-tests (Lachema, Brno, Czech Rep.). Protein contents in samples was measured according to L o w r y et al. (1951). Student's $t$-test was used for the statistical evaluation of the significance of the differences.

\section{Results}

Lactate dehydrogenase belongs to principal glycolytic enzymes. As expected, its activity was higher in cytosol than in mitochondria (Tables 1,2). Malate dehydrogenase and 2-oxoglutarate dehydrogenase function in the citric cycle and their activities were, therefore, higher in mitochondria than in cytosol. Arginase and ornithine carbamoyltransferase are enzymes of the urea cycle. The former enzyme was more active in the cytosolic fraction, whereas the latter one had higher activity in mitochondria. Activity of aspartate aminotransferase was higher in mitochondria than in cytosolic fraction. Activity of alanine aminotransferase was almost uniformly distributed in both fractions of the cellular material.

Table 1

Enzymatic activities ${ }^{1}$ in samples of musculus longissimus dorsi from control and monensin-fed steers

\begin{tabular}{|lccccc|}
\hline \multirow{2}{*}{ Enzyme $^{2}$} & \multicolumn{2}{c}{ Mitochondria } & & \multicolumn{2}{c|}{ Cytosolic fraction } \\
\cline { 2 - 3 } \cline { 5 - 6 } & Control & Monensin & & Control & Monensin \\
\hline LDH $^{3}$ & $22.7 \pm 2.8$ & $23.7 \pm 2.0$ & & $2039 \pm 40$ & $2008 \pm 218$ \\
\hline MDH $^{4}$ & $2279 \pm 267$ & $2327 \pm 428$ & & $367 \pm 45$ & $424 \pm 15$ \\
\hline OGDH $^{5}$ & $32.3 \pm 2.3$ & $44.3 \pm 3.7^{*}$ & & $22.0 \pm 3.4$ & $29.5 \pm 2.0^{*}$ \\
\hline GDH $^{6}$ & $20.6 \pm 3.0$ & $16.5 \pm 1.7^{*}$ & & $6.4 \pm 0.6$ & $4.8 \pm 0.6^{*}$ \\
\hline GS $^{7}$ & $2.1 \pm 0.7$ & $1.4 \pm 0.3$ & & $0.7 \pm 0.1$ & $0.8 \pm 0.1$ \\
\hline $\mathrm{A}^{8}$ & $92.7 \pm 26.7$ & $79.6 \pm 6.3$ & & $332 \pm 67$ & $333 \pm 79$ \\
\hline OCT $^{9}$ & $13.8 \pm 2.3$ & $8.1 \pm 0.8$ & $6.9 \pm 0.7$ & $7.7 \pm 1.2$ \\
\hline AST $^{10}$ & $39.3 \pm 2.0$ & $37.9 \pm 2.4$ & $4.0 \pm 0.3$ & $4.0 \pm 0.4$ \\
\hline ALT $^{11}$ & $5.1 \pm 2.6$ & $4.0 \pm 0.6$ & $4.5 \pm 0.2$ & $4.4 \pm 0.4$ \\
\hline
\end{tabular}

1) Per $1 \mathrm{mg}$ of protein, ${ }^{2)}$ see"Material and Methods" for explanation,

3) $\mathrm{nmol} \mathrm{NADH} / \mathrm{min},{ }^{4)} \mathrm{nmol} \mathrm{NADP} / \mathrm{min},{ }^{5)} \mathrm{nmol}$ NAD/min, ${ }^{6}$ nmol NADPH/min,

7) nmol glutamylhydroxamate/h, ${ }^{8)} \mathrm{nmol}$ urea/min,,9) $\mathrm{nmol} \mathrm{NH} 3 / \mathrm{min}$,

10) $\mathrm{nmol}$ oxaloacetate/min, ${ }^{11)} \mathrm{nmol}$ pyruvate/min

*Significantly different from control at $\mathrm{P}<0.05$ 
Table 2

Enzymatic activites ${ }^{1}$ in samples of heart tissue from control and monensin-fed steers

\begin{tabular}{|lcccc|}
\hline \multirow{2}{*}{ Enzyme } & \multicolumn{2}{c}{ Mitochondria } & \multicolumn{2}{c|}{ Cytosolic fraction } \\
\cline { 2 - 5 } & Control & Monensin & Control & Monensin \\
\hline LDH $^{3}$ & $47.2 \pm 5.5$ & $68.0 \pm 6.2^{*}$ & $129 \pm 12$ & $271 \pm 35^{*}$ \\
\hline MDH $^{4}$ & $5255 \pm 513$ & $5491 \pm 325$ & $2615 \pm 273$ & $2928 \pm 196$ \\
\hline OGDH $^{5}$ & $34.0 \pm 3.7$ & $56.5 \pm 4.4^{*}$ & $13.0 \pm 0.7$ & $13.1 \pm 0.8$ \\
\hline $\mathrm{GDH}^{6}$ & $10.1 \pm 1.9$ & $10.7 \pm 1.54$ & $0 \pm 0.3$ & $3.6 \pm 0.3$ \\
\hline $\mathrm{GS}^{7}$ & $1.14 \pm 0.34$ & $1.32 \pm 0.26$ & $1.4 \pm 0.1$ & $1.4 \pm 0.1$ \\
\hline $\mathrm{A}^{8}$ & $31.5 \pm 4.7$ & $51.4 \pm 6.5^{*}$ & $245 \pm 54$ & $256 \pm 24$ \\
\hline $\mathrm{OCT}^{9}$ & $61.4 \pm 7.2$ & $125.2 \pm 8.9^{*}$ & $8.6 \pm 1.0$ & $7.8 \pm 1.8$ \\
\hline $\mathrm{AST}^{10}$ & $5.2 \pm 0.6$ & $8.4 \pm 0.7^{*}$ & $4.0 \pm 0.2$ & $3.8 \pm 0.2$ \\
\hline $\mathrm{ALT}^{11}$ & $5.3 \pm 0.5$ & $8.9 \pm 1.5^{*}$ & $4.5 \pm 0.2$ & $4.2 \pm 0.3$ \\
\hline
\end{tabular}

For ${ }^{1)}$ - 11) see Table 1

* Significantly different from control at $\mathrm{P}<0.005$

Monensin increased activity of 2-oxoglutarate dehydrogenase and decreased activity of glutamate dehydrogenase in both fractions of the skeletal muscle tissue (Table 1). Enzymatic activities found in heart mitochondria were higher in monensin-fed steers (Table 2). In six out of nine enzymes the effect was statistically significant.

Steers given monensin gained $8.23 \%$ more than control steers (263 kg vs $243 \mathrm{~kg}$ ). No health problems were encountered in the duration of experiment.

\section{Discussion}

The ionophores are defined as compounds which form lipid soluble cation complexes able to transport ions across biological membranes. Effect of ionophores on eukaryotic cells appears to involve the disruption of endomembrane function, particularly membranes associated with the Golgi apparatus (W e e t e et al. 1989). The resultant changes in ion gradients and electrical potentials often influence cellular functions. Calcium ionophores inhibited the glucose-stimulated release of insulin from pancreatic islets of mice (H e $11 \mathrm{~m}$ a $\mathrm{n}$ 1975). Monensin stimulated the release of glucuronidase, hexosaminidase and galactosidase by mouse peritoneal macrophages ( $\mathrm{T}$ a $\mathrm{n}$ a $\mathrm{k}$ o et al. 1984), stimulated catecholamine secretion (P e r $\mathrm{m}$ a n et al. 1980) and inhibited the secretion of procollagen and fibronectin (U ch id a et al. 1979).

In this study monensin fed to steers for 10 months increased activity of enzymes in heart mitochondria. Effect of monensin on musculus longissimus dorsi cells was much less pronounced. The heart tissue is particularly sensitive to toxic doses of monensin ( $\mathrm{G}$ a $1 \mathrm{i} \mathrm{t} \mathrm{z} \mathrm{e} \mathrm{r} \mathrm{et} \mathrm{al.} \mathrm{1983).} \mathrm{On} \mathrm{the} \mathrm{other} \mathrm{hand,} \mathrm{low} \mathrm{doses} \mathrm{of} \mathrm{carboxylic} \mathrm{ionophores}$ stimulate cardiac contractility, coronary flow, and these agents may be desirable drugs for treating the low cardiac output syndrome ( $\mathrm{P} \mathrm{r}$ e s s $\mathrm{m}$ a $\mathrm{n}$ and $\mathrm{F} \mathrm{a} \mathrm{h} \mathrm{i} \mathrm{m} \mathrm{1982).} \mathrm{Cell}$ 
activation, which is probably calcium-mediated, requires monensin concentrations between $10^{-8}$ and $10^{-6} \mathrm{M}$.

Mitochondrial membranes were probably damaged after freezing and crushing of tissue samples. Mitochondrial enzymes thus could contaminate cytosolic fraction to some extent. However, when in a separate experiment the deep freezing was omitted in GDH assay, proportion of GDH activity present in mitochondrial and cytosolic fraction of cells of the rat cardiac tissue was not very different from those shown in Table 1 and 2 ( $45.5 v s 11.1 \mathrm{nmol}$ $\mathrm{NADPH} / \mathrm{min} . \mathrm{mg}$ ). Our results thus document that long-term supplementation of monensin to ruminants can influence cardiac metabolism at subcellular level.

\section{Aktivita dehydrogenáz a enzymů metabolismu dusíku v srdečním a kosterním svalu býků krmených dávkou s př́davkem monensinu}

Zjištovali jsme účinek monensinu na aktivitu intracelulárních enzymů v tkáni srdce a kosterním svalu (musculus longissimus dorsi) býků krmených senem, siláží a koncentrátem. Věk býkủ na začátku pokusu byl 9 měsícủ. Pět býkủ dostávalo po 10 měsíců monensin v množství $0,5 \mathrm{mg} / \mathrm{kg}$ živé hmotnosti denně. Pět býků bylo kontrolních. Po porážce jsme stanovili aktivitu devíti enzymů $\mathrm{v}$ mitochondriální a cytoplasmatické frakci buněk : laktátdehydrogenázy (E.C.1.1.1.27), malátdehydrogenázy (E.C.1.1.1.40), 2-oxoglutarátdehydrogenázy (E.C.1.2.4.2), glutamátdehydrogenázy (E.C.1.4.1.3), glutaminsyntetázy (E.C.6.3.1.2), arginázy (E.C.3.5.3.1), ornitinkarbamoyltransferázy (E.C.2.1.3.3), aspartátaminotransferázy (E.C.2.6.1.1) a alaninaminotransferázy (E.C.2.6.1.2).Monensin zvýšil aktivitu 2-oxoglutarátdehydrogenázy a snížil aktivitu glutamátdehydrogenázy $\mathrm{v}$ obou frakcích buněk kosterního svalu. Aktivity mitochondriálních enzymů buněk srdečního svalu byly u býků krmených dávkou s monensinem vyšši než u býků kontrolních. Hmotnostní prírůstky býků krmených dávkou s monensinem byly o 8,23 \% vyšší než u kontroly ( 263 vs $243 \mathrm{~kg})$.

\section{Acknowledgement}

The authors thank the Grant Agency of the Czech Republic for the partial support of this study.

\section{References}

ARMSTRONG J. D,. SPEARS J. W. 1988: Intravenous administration of ionophores in ruminants: Effects on metabolism independent of the rumen. J. Anim. Sci. 66: 1807-1817

BENZ D. A., BYERS F. M., SCHELLING G. T., GREENE L. W., LUNT D. K., SMITH S. B. 1989 : Ionophores alter hepatic concentrations of intermediary carbohydrate metabolites in steer. J. Anim. Sci. 67: 2393-2399

COLOWICK S. P., KAPLAN N. O. 1955: Methods in Enzymology, Vol.I, pp. 368-753, Academic Press, Inc., New York

COLOWICK S. P., KAPLAN N. O.1955: Methods in Enzymology, Vol. II, pp. 220-443, Academic Press, Inc., New York

DAVISON K. L. 1983: Metabolism of $\left[{ }^{14} \mathrm{C}\right]$ monensin by calves. J. Anim. Sci. 57 (Suppl. 1): 301

DONOHO A. L. 1984: Biochemical studies on the fate of monensin in animals and in the environment. J. Anim. Sci. 58:1528-1539

GALITZER S. J., KRUCKENBERG S. M., OEHME F. W., BARTLEY E. E., KIDD J. R. 1983: Blood chemistry and tissue changes in lasalocid or monensin toxicity of cattle. J. Anim. Sci. 57 (Suppl. 1):302-303

HELLMAN B. 1975: Modifying actions of calcium ionophores on insulin release. Biochim. Biophys. Acta 399:157-169

HOGEBOOM G. 1955: Fractionation of cell components of animal tissues. In: Methods in Enzymology, Vol. I, pp. 16-19, Academic Press, Inc., New York 
KALAČNJUK G. I., MAROUNEK M., GERASYMIV M. G., SAVKA O. G., KALAČNJUK L. G. 1993: Activity of dehydrogenases and enzymes of nitrogen metabolism in rumen mucosa and liver of steers fed monensin. Acta vet. Brno 62:127-131

LOWRY O. H., ROSEBROUGH N. J., FARR A. L., RANDALL R. J. 1951: Protein measurement with the Folin phenol reagent. J. Biol. Chem. 193:265-275

MAROUNEK M., SKŘIVANOVÁ V., MACHAŇOVÁ L. 1989: Effect of monensin on digestibility of nutrients, ruminal volatile fatty acids and blood parameters in young calves. Landwirtsch. Forschung 42:273-280

MORTON R. K. 1955: Methods of extraction of enzymes from animal tissues. In : Methods in Enzymology, Vol. I, pp. 25-51, Academic Press, Inc., New York

PERLMAN R. L., COSSI A. F., COLE L. W. 1980: Mechanism of ionophore induced catecholamine secretion. J. Pharmacol. Exp. Ther. 213:241-246

PRESSMAN B. C., FAHIM M. 1982: Pharmacology and toxicity of the monovalent carboxylic ionophores. Ann. Rev. Pharmacol. Toxicol. 22:465-49O

TANAKO Y., IMAI K., TANAKA A., FUJIMORI K., YAMADA M., YAMAMOTO K. 1984: Stimulation of the release of lysosomal and non-lysosomal granular enzymes from macrophages treated with monensin. Cell Struct. Funct. 9:265-267

TODD G. C., NOVILLA M. N., HOWARD L. C. 1984: Comparative toxicology of monensin sodium in laboratory animals. J. Anim. Sci. 58:1512-1517

UCHIDA N., SMILOWITZ H., TANZER M. L. 1979: Monovalent ionophores inhibit secretion of procollagen and fibronectin from cultured human fibroblasts. Proc. Natl. Acad. Sci. USA 76:1868-1872

VAN VLEET J. F., AMSTUTZ H. E., REBAR A. H. 1985: Effect of pretreatment with selenium - vitamin E on monensin toxicosis in cattle.. Amer. J. Vet. Res. 46:2221-2228

WEETE J. D., EL MOUGITH A., TOUZE-SOULET J.-M. 1989: Inhibition of growth, lipid, and sterol biosynthesis by monensin in fungi. Exp. Mycol. 13:85-94

Address for correspondence:

M. Marounek

Institute of Animal Physiology and Genetics

10400 Prague 10 - Uhříněves

Czech Republic 